\title{
Effect of SPIKES-based Education by Role Playing and Multimedia Approaches on Breaking Bad News Skills in Midwifery Students (a Comparison)
}

\author{
Nasrin Baghdari ${ }^{1}$, Mostafa Rad ${ }^{2}$, Marzie Torkmannejad Sabzevari² \\ ${ }^{1}$ Mashhad University of Medical Sciences, Mashhad, Iran \\ ${ }^{2}$ Nursing and Midwifery School, Sabzevar University of Medical Sciences, Sabzevar, Iran
}

\begin{abstract}
SUMMARY
Due to the diversity of midwives' responsibilities, the skill to deliver bad news is a vital need, and therefore the teaching approach in this matter is of utmost importance. Thus, this study has been conducted with the purpose of comparing the effect of SPIKES-based education of skills needed for delivering bad news, using two different approaches of role playing and multimedia in midwifery students.

This double-blind clinical trial was done on $\mathbf{9 0}$ midwifery students who were randomly assigned to three separate groups. Students' skill in delivering bad news was recorded through a specific checklist before and after the educational intervention. The reliability and validity of this skill evaluation checklist was assessed and confirmed. The final data were analyzed using SPSS software.

After educational intervention, role playing and multimedia groups have gained more skills compared to their previous conditions as well as the control group. The skill of delivering bad news did not show a significant difference in role playing and multimedia groups after intervention.

The results showed that teaching the skills of delivering bad news using multimedia approach which was held as distance learning course would rival active educational methods such as role playing. Thus, it could be a suitable replacement for role playing methods in increasing the skill needed for delivering bad news.
\end{abstract}

Key words: role play, multimedia, breaking bad news, midwifery, SPIKES

Corresponding author:

Mostafa Rad

Email: mostafarad633@yahoo.com 


\section{INTRODUCTION}

Delivering bad news is a routine but difficult responsibility of medical care personnel (1). This situation is a critical point in clinical communications which would expose both the patient and the deliverer to an uncomfortable feeling as well as a considerable mental and psychological distress (2). Robert Beckman defines bad news as "any information which adversely and seriously affects an individual's view of his or her future" (3).

Irresponsible and immoral approach of health care personnel in delivering bad news could highly affect the outcome of the situation and the probability of non-acceptance, non-adjustment, and even unexpected actions from the patient $(4,5)$. Based on the moral guidelines and patients' rights, they have the right to be informed about their health status in an accurate and timely manner, and the presentation of this information should be under standard protocols and professional and general moral principles (6). Midwifery profession with its long and diverse range of activities in private clinics, health care centers, consulting agencies, maternity hospitals, and emergency departments should always be prepared for challenging situations in which bad news must be delivered. While in Iran midwives do not follow a specific protocol in delivering bad news $(7,8)$, Sereshti et al, in their descriptive cross-sectional study on midwives, nurses, and faculty members, reported that $92.6 \%$ of people believed that holding workshops on proper delivery of bad news is a necessity, and $77.6 \%$ of them admitted that they had had problems in delivering such news (7). Right now, there is not an academic and official course on deliverance of bad news and related clinical communications, and such skills are generally achieved through indirect methods such as observation of peers and masters as well as experience (8). Various strategies have been suggested for delivering bad news which are all based on the same principles:

1. Preparation and setup;

2. Delivering the bad news;

3. Managing emotions and feelings;

4. Planning future steps and proceedings;

5. Referring to experts in case of need (3).

SPIKES strategy was suggested by Robert Brickman in 1992 as a guideline for delivering bad news; it's consisted of 6 steps as following:

1. SETTING UP the interview

2. Assessing the patient's PERCEPTION

3. Obtaining the patient's INVITATION
4. Giving KNOWLEDGE and information to the patient

5. Addressing the patient's EMOTIONS with empathic responses

6. STRATEGY and SUMMARY (4).

Considering the educational needs of midwifery field, it can be said that the most important step in teaching the required skills in delivering the bad news is choosing an appropriate educational method and environment. The quality of learning is directly related to the quality of education and choosing a suitable and effective approach plays a significant role in that matter (9). Karimi Moonaghi et al. (1392) in their systematic overview on "evaluating the effectiveness of modern teaching methods" reported that higher rate of learning, increased satisfaction and durability of the information, more participation and cooperation, elevating communicational skills, building the interest for learning and reading skills, and development of critical thinking are all the benefits of modern education comparing to traditional and teacher-based methods. Group discussions, role playing, problem solving, metacognitive learning packages, and e-learnings are among notable modern educational approaches (10).

Teaching the skills needed for delivering bad news consists of emotional and observational purposes as well as increasing clinical communication skills. Since role playing approach could visually create the desired situation, it could be a suitable method for emotional purposes as well as changing approaches, values, and perceptions of people and improving their skills, especially in communicational areas. Managheb et al. (2011) in their study on comparing the effect of role playing and group discussion on the skill needed for delivering bad news reported that their difference was significant as their effect and role playing approach had been proved to be a more effective method (11). Although role playing could help achieving various educational goals, it needs physical appearance in traditional courses which could be an issue in modern societies due to timing limitations; therefore, distance e-learning methods using computers and other modern equipment have found their place in medical education (12). Wang et al. (2012) reported that using multimedia has proved to be beneficial in improving doctors' behaviors and respecting moral principles in their jobs (13). Since traditional courses need appropriate facilities, conditions, and human resources, distance learning could also be a cost-effective approach in this regard. Moreover, these methods are more flexible and provide the 
student with benefits such as having enough time for practice and repetition for more comprehensive learning (14). As there is an alarming distance between learning and action, designing an appropriate test to evaluate taught skills is a must (15). A satisfactory and reliable test such as OSCE could be useful in this study and other similar researches of the same magnitude (16). No other published research has been found regarding the evaluation of the effect of distance and traditional student-based educational methods on the skills needed for delivering bad news; therefore, the author decided to evaluate the effect of SPIKES-based education with two different approaches of role playing and multimedia on improving the skills needed for delivering bad news in midwifery students of Mashhad's University of Medical Sciences.

\section{MATERIAL AND METHODS}

\section{Participants and Procedures}

This three-group double-blind clinical trial was conducted in Mashhad's University of Medical Sciences in 2015 after acquiring the necessary permissions from the Ethics Committee. The sample size was 90 persons and the research population was midwifery students of Mashhad University who had a bachelor's or master's degree. The students were assigned to three equal groups of role playing, multimedia, and control using permutated block randomization method. Including criteria were hospital internship experience, no previous record of mental and psychological disorders, no bad news received in the last three months (death in the family, diagnosis of incurable diseases, selfdisability or similar cases in the family), and no previous participation in courses or workshops regarding the skills of breaking bad news. Excluding criteria were receiving bad news in the period between entry and post-study phase, no participation in teaching processes or tests, using multimedia packages for less than three hours, and refusal and lack of interest. In order to evaluate the students' skills, standardized patient and Objective Structured Clinical Examination (OSCE) was used. In this study, three standard patients received the required instructions based on three pre-designed scenarios to achieve the needed skills. Designed scenarios included news delivery report on high squamous intra epithelial lesion (HSIL) in squamous cells of the cervix, abortion after infertility treatment, and new born's craniofacial anomaly.

\section{Measures}

Demographic information questionnaire was structured by document review and related article. A self-made checklist was used to collect data; its content validity was confirmed by seven masters of midwifery, psychology, and psychiatry departments. Its reliability was also confirmed using Cronbach's alpha test of internal consistency with the score of $83 \%$. The checklist was designed with Yes/No answers, and in case of performing the required skill, a score of 1 was given, and in case of mistakes or non-performance of the desired skill, a score of 0 would be assigned. The highest total score in all three groups based on the designed checklists was 79 , while the lowest was 0 . The number of items in the checklist was 27,24 , and 28 for three groups, respectively.

\section{Intervention}

At the start of the study, students filled the required form and entered the study consciously and willingly. At pre-test phase, regardless of their groups, all participants were assessed by educated experts who did not have any information on group assignments. Inter-rater reliability was measured to be 0.86 using Cohen's kappa test. In multimedia group, a learning package was offered to the participants, which included the principles of breaking bad news based on SPIKES strategy in the form of a speech complemented with a 45-minutes PowerPoint file and five 15-minute educational clips as well as a video clip on clinical communication. A form was also attached to the packages in which the participants should have recorded the using times. In the role playing group, a 45-minute speech was presented along with practical demonstration of SPIKES strategy principles based on pre-designed scenarios in which six students volunteered for playing as midwives and patients; after studying the scenarios, each two volunteers performed one of the scenarios for 15 minutes, and all other students assessed their performance using the specific checklist designed for role playing sessions. After sessions, a 15-minute feedback on the performance was provided with the help of the author to stress its pros and cons. Then, the performance was repeated in a correct manner, based on the principles of SPIKES strategy. This procedure was done for all designed scenarios. Educational content was completely identical in both groups. No educational intervention was done on the control group. Two weeks after 
educational process, post-test procedure started in which the results of pre-test and post-test of all groups were compared together.

Collected data was entered in SPSS (Version 23) software, and eventually analyzed using descriptive and inferential statistics including mean and standard deviation, and parametric and non-parametric tests such as Chi-square and one-way analysis of variance
(ANOVA). The significance level was set at 0.05.

\section{Data analyst}

All data collected through the questionnaire and checklists were statistically analyzed regarding the study aims. These data analyzed using SPSS version 23.

Table 1: Comparison of mean score of skills needed for delivering bad news before intervention in three groups of role play, multimedia, and control

\begin{tabular}{c|c|c|c}
\hline \hline Group & Control & Multimedia & Role-play \\
\hline Statistical index & mean \pm S.D & mean \pm S.D & mean \pm S.D \\
\hline $\begin{array}{c}\text { Breaking bad news Skills } \\
\text { before education }\end{array}$ & $20 / 5 \pm 6 / 9$ & $20 / 8 \pm 5 / 5$ & $\mathbf{2 0 / 6 \pm 4 / 9}$ \\
\hline Test of ANOVA & $\mathrm{df}=2$ & $\mathrm{~F}=0 / 142$ & $\mathbf{P}=\mathbf{0} / \mathbf{8 6 8}$ \\
\hline \hline
\end{tabular}

Table 2: Comparison of the mean score of skills needed for delivering bad news after intervention in the three groups of role play, multimedia, and control

\begin{tabular}{|c|c|c|c|}
\hline \multicolumn{2}{|c|}{ Groups } & p-value & $\begin{array}{c}\text { Mean difference } \pm \text { SD } \\
\text { between groups }\end{array}$ \\
\hline Role-play & $\begin{array}{l}\text { Multimedia } \\
\text { control }\end{array}$ & $\begin{array}{l}0 / 268 \\
0 / 000\end{array}$ & $\begin{array}{l}-2 / 4 \pm 1 / 6 \\
26 / 3 \pm 1 / 5\end{array}$ \\
\hline Multimedia & $\begin{array}{l}\text { Role-play } \\
\text { control }\end{array}$ & $\begin{array}{l}0 / 268 \\
0 / 000\end{array}$ & $\begin{array}{l}-2 / 4 \pm 1 / 6 \\
28 / 5 \pm 1 / 2\end{array}$ \\
\hline Control & $\begin{array}{l}\text { Role-play } \\
\text { Multimedia }\end{array}$ & $\begin{array}{l}0 / 000 \\
0 / 000\end{array}$ & $\begin{array}{l}-26 / 3 \pm 1 / 5 \\
-28 / 5 \pm 1 / 2\end{array}$ \\
\hline \multicolumn{3}{|c|}{$\mathrm{P}=0 / 000$} & $\mathrm{~F}=343 / 41$ \\
\hline
\end{tabular}

\section{RESULTS}

The mean age of participants was $23.44 \pm 0.4$ years. Among participants, 71 (78.9\%) were bachelor's degree students, while 19 (21.1\%) were master's degree students. Average academic scores of the participants was $16.26 \pm 1.2$. Regarding their employment status, 83 (92.2\%) participants were unemployed, while just 7 $(7.8 \%)$ were employed at the time of the study. Thirtytwo participants (35\%) were married, while 57 (63.9\%) were single, and the other one was a divorcee. Nine (10\%) students had a previous experience of delivering bad news, whereas 81 (90\%) participants did not. Demographic distribution was balanced in all three groups in a way that ANOVA test as well as Chi-square test did not show a significant difference regarding this matter $(\mathrm{P}<0.05)$. A comparison of mean score of skills in all three groups of role playing, multimedia, and control before intervention through ANOVA test did not show a significant difference statistically $(\mathrm{P}=$ 0/868) (Table 1). There is a significant difference in mean skill score of role play and multimedia groups when compared to the control group after educational intervention, while the same could not be said about the control group. In comparing mean skill score of role play and multimedia groups after the intervention, no significant difference was detected (Table 2).

\section{DISCUSSION}

In this research on midwifery students, there was a significant increase, after intervention, in the score assigned to the skills needed for breaking bad news in both role play and multimedia groups. In the control group, this was not the case and no significant 
difference was detected after the intervention. In two against two comparisons, an increased skill score of role play and multimedia groups did not show a significant difference. In Managheb et al. study (2011) in which two student-based approaches of physical classes and group discussions were used, the score of the skills needed for delivering bad news showed a significant increase in both groups, which is in line with this research (11). Although in role play group the increase in scores was relatively higher when compared to multimedia group which could be due to its greater dynamism and attraction to students as well as closeness and better understanding of real situations. The fact that group discussion as a studentbased physical approach has had less success in improving students' skills compared to role play approach could be due to the power of role play approach in creating real life clinical situations as well as interpersonal communications. None et al. (2013) studies have shown that compared to traditional methods, role playing approach is more effective in teaching the communicational skills needed for treating patients and delivering bad news (17). In fact, role play approach is an educational approach that is largely used in teaching communicational skills. In this method, the student would be placed in a desired situation and should act accordingly which would help him to learn the proper approaches toward similar situations and challenges. It can be said that the process of role playing would act as a real-life model of human behavior through which the students can understand feelings and could acquire a certain insight corresponding to their values and viewpoint $(18,19)$.

Academic subjects, diversity of educational goals, and environmental conditions such as time and location could be the factors in choosing the best and most effective educational approach. Therefore, one educational method could not be introduced as the definitive and most effective approach. Ebadi et al. conducted a study called "comparing the effect of traditional (face to face) and distance training on clinical skills of nurses". Mean of total scores of nurses' clinical skills did not show a significant difference after intervention in both physical training and multimedia (distance) approach (19). Moreover, Toledo et al. in their study on the effect of web-based education, compared to real-life simulation, reported that the mean score of OSCE test did not show a significant difference in both groups (20). The results of all aforementioned studies are in line with this research. Another factor that could be important in the effect of multimedia- based methods on learning is its ability to adjust with student's needs and potentials (21). Students can use the multimedia package as an on-access learning instrument as many times as they want, at any desired time, and in any location. Gartemeier et al. in their effort on teaching communicational skills needed for relating to patients and parents to medical students and teacher education trainees reported that electronic teaching methods as well as video presentations have been significantly more effective than role playing approaches, which is not in keeping with the results of this study (22). This issue could be associated to the implementation of electronic instruments with physical and face to face approach, and thus better controlling of the students regarding their usage of the contents, which has improved the focus on the educational materials and therefore has improved its effect compared to role play approach. On the other hand, in eteaching physical classes, there is also the possibility of first-hand information exchange as well as discussion between students and tutors which could greatly help in educational process. Alijanpour et al. research on comparing the effect of face to face and multimedia training in improving cardiopulmonary resuscitation skills in medical students revealed that knowledge and performance of the first group, which included practical demonstrations and educational speeches, were more improved compared to multimedia group (23). This contrasting conclusion could be due to the different approach in using multimedia packages. In that research, although the e-teaching approach has been implemented in physical classes, its effectiveness has been reduced due to the lack of time. Comparing this study with previous publications could clearly demonstrate the importance of time in multimedia teachings. Meshki et al. conducted a research on effectiveness of educational programs in nutrition status of pregnant women with focus on comparing group discussion and multi-media approaches. Both methods improved the nutrition status of pregnant women compared to control group after the intervention. Comparison of the two approaches revealed that the group discussion method is significantly more effective (24). The content of multi media package in this study was more focused on improving the knowledge and information of pregnant women regarding their required diet and vitamins rather than changing their eating habits and approaches. Therefore, educational content of multi-media packages are also an important factor behind improved knowledge, approach, and performance. Self-directing non-physical methods such as pre- 
designed educational packages should have enough attractions and innovation, so it could be able to compete with other approaches. Mazani et al. study on the differences between face to face and distance educational approaches towards teaching mothers regarding the anthropometric changes of their new-borns confirmed this matter as its results revealed a significant difference between both methods with face to face approach being more effective (25). In this study, an illustrated booklet was used for distance education which is a non-interactive and tedious method and has not enough attractions to motivate learners. Considering the findings of this research and its comparison with other similar studies, it seems that the most important effect of role play and multimedia approaches in improving the performance of learners is increasing their analysis and thinking abilities as well as involving their emotions through demonstrating proper performances against improper ones and their consequences.

\section{Limitations}

Using control group in evaluating the effect of time and maturation of research units, then rendering time forms in multimedia group for confirming the study of contents, and conforming intervention time in role play and multimedia group were strengths of this study.

Restriction of the study to just one university, and inability to prevent groups from exchanging information were among the study's weakness. In order to prevent the contents of multimedia packages to get copied, coded CDs were used. Another strategy used to prevent distribution of educational content was reduction of the timeframe of the study.

\section{CONCLUSION}

Both multimedia and role play approaches proved to be effective in improving the skills needed for breaking bad news. The effectiveness of educational multimedia packages using distance learning with their innovation, attraction, increased focus, and time and location flexibility could rival active face to face approaches such as role play method in improving the skills needed for delivering bad news. Considering the importance of knowledge in midwives' skills as well as limited resources on human and time fronts in modern societies, in order to improve the proper communica tion toward grieving patients and breaking bad news based on SPIKES strategy, distance education using multimedia approach with its wide range of abilities and benefits could be a viable option. Further research in this field is recommended.

\section{Acknowledges}

This article is a part of master's degree thesis which has been approved in Nursing and Midwifery University of Mashhad. We like to thank Research Deputy of Mashhad's University of Medical Sciences who supported this project financially. We also appreciate the efforts of all students who participated in this research. 


\section{References}

1. Shomoossi N, Rad M. Kooshan M, Ganjloo J. Nurses as Death Notifiers: a Report from Nurses in Iran. Life Science Journal. 2013;10(4s).

2. Shaw J, Brown R, Heinrich P, Dunn S. Doctors' experience of stress during simulated bad news consultations. Patient EducCouns 2013; 93(2):203-8.

https://doi.org/10.1016/j.pec.2013.06.009

3. Baile WF, Buckman R, Lenzi R, et al. SPIKES-a six-step protocol for delivering bad news: application to the patient with cancer.

Oncologist 2000-5(4):302-11.

https://doi.org/10.1634/theoncologist.5-4-302

4. Ahmadi A, Heydari N. Is there a proper method of truth telling? J Med Ethics Hist Med 2010;3(2):16-28.

5. McGuigan D. Communicating bad news to patients: a reflective approach. Nurs Stand 2009;23(31):51.

https://doi.org/10.7748/ns.23.31.51.s49

6. Kazemi A.The medical invierment, pationt and bad news. Strides Dev Med Educ 2008;

3(2):133-9[Persian].

7. Sereshti M, Izadi A. The attitudes of health care providers toward breaking bad news in neonatal intensive care units and labor wards. J Med Ethics HistMed2013; 6(4)57-67.[Persian].

8. Taghizadeh Z, Rezaiepour A, Mehran A, Alimoradi Z. Usage of communication skills by midwives and its relation to clients' satisfaction. Hayat. 2006; 12 (4):47-55 [Persian].

9. Entwistle NJ. Styles of learning and teaching: An integrated outline of educational psychology for students, teachers and lecturers: Routledge; David Fulton Publishers, 2013.
10. Moonaghi HK, Rad M, Bakhshi M. Do the new methods of teaching in medical education have adequate efficacy?: A systematic review. Strides Dev Med Educ. 2013;10(2):271-80.

11. Managheb SE, Mosalanejad N. Teaching How to Break Bad News: Comparing Role-Play and Group Discussion on Practice of Medical Interns in Jahrom Medical School. Iranian J Med Educ 2012; 11 (7) :789-97

12. Ba-ados, Emerita. A blended-learning pedagogical model for teaching and learning EFL successfully through an online interactive multimedia environment. CALICO Journal. 2013;23(3): 533-50.

13. Wang P-W, Chen R-C, Chang S-Y. Assessment of Hospital Staff Satisfaction and Training Outcome Receiving Medical Ethics Education on Disclosure Using Multimedia Case Teaching Video.2012;16(2):9-15.

http://dorise.sec.ntnu.edu.tw/main/

14. Dolhalit ML, Salam SNA. Exploring Persuasive Multimedia Techniques in Attitude and Behavior Change: A Comparative Study. Procedia Soc Behav Sci. 2014;155:386-91.

https://doi.org/10.1016/j.sbspro.2014.10.310

15. Heydari A, Rad M, Rad M. Evaluating the Incivility between Staff Nurses and Matrons Employed in Iran/Procena nepristojnog ponašanja u međusobnom odnosu medicinskih sestara i glavnih medicinskih sestara zaposlenih $u$ Iranu. Acta Facultatis Medicae Naissensis. 2015;32(2): 137-46.

https://doi.org/10.1515/afmnai-2015-0014

16. Taylor CA, Green KE. OSCE Feedback: A Randomized Trial of Effectiveness, Cost-Effectiveness and Student Satisfaction. Creative Education. 2013;4(06):9. 
17. Noone PH, Sharma SR, Khan F, Raviraj K, Shobhana S. Use of role play in undergraduate teaching of ethics-An experience. J Forensic Leg Med 2013;20(3):136-8. https://doi.org/10.1016/j.jflm.2012.06.010

18. Kesten KS. Role-play using SBAR technique to improve observed communication skills in senior nursing students. J Nurs Educ 2011;50(2): 79-87. https://doi.org/10.3928/01484834-20101230-02

19. McCaffrey R, Hayes RM, Cassell A, et al. The effect of an educational programme on attitudes of nurses and medical residents towards the benefits of positive communication and collaboration. J Adv Nurs 2012;68(2):293-301.

https://doi.org/10.1111/j.13652648.2011.05736.x

20. Toledo P, Eosakul ST, Goetz K, et al. Decay in blood loss estimation skills after web-based didactic training. Simul Healthc2012;7(1):18 21.

https://doi.org/10.1097/SIH.0b013e318230604f

21. Khan MR, Epperson MW, Gilbert L, et al. The promise of multimedia technology for STI/HIV prevention: Frameworks for understanding improved facilitator delivery and participant learning. AIDS Behav2012;16(7):1949-60. https://doi.org/10.1007/s10461-011-0106-9

22. Gartmeier M, Bauer J, Fischer MR, et al. Fostering professional communication skills of future physicians and teachers: effects of elearning with video cases and role-play. Instr Sci2015:1-20. https://doi.org/10.1007/s11251-014-9341-6

23. Alijanpour E, Amri P, Khafri S, Razaghi oji talari F, Assessment of different cardiopulmonary resuscitation teaching approach on quality of education in medical student, Babol. Iran J Basic Med Sci 2014;6(56):376-382.

24. Moshki M, Seyedesani SK, Shafaghi K, Effectiveness of training programs on nutritional status during pregnancy: Comparison of group discussion method and multi-media package. IJOGI 2014;17(128): 18-27.[Persian].

25. Mazani M, Arbabi HI, Mashoufi M, Mahdavi $\mathrm{R}$, Comparing the Effectiveness of Attendance and Non Attendance Education of Health Workers on Knowledge of Mothers and Anthropometric Changes of Infants. J Ardabil Univ Med Sci2011;3(1):7486.[Persian]. 


\title{
Efekti edukacije zasnovane na SPIKE strategiji kroz igranje uloga i korišćenje multimedijalnih sadržaja na sticanje veština objavljivanja loših vesti od strane studenata fakulteta za sestrinstvo i akušerstvo
}

\author{
Nasrin Baghdari ${ }^{1}$, Mostafa Rad ${ }^{2}$, Marzie Torkmannejad Sabzevari² \\ ${ }^{1}$ Univerzitet Medicinskih nauka Mashhad, Mashhad, Iran \\ ${ }^{2}$ Fakultet za sestrinstvo i akušerstvo, Univerzitet medicinskih nauka u Sabzevaru, Sabzevar, Iran
}

\section{SAŽETAK}

Zbog velikog broja odgovornosti sa kojima se babice susreću u svom poslu, nameće se potreba sticanja veštine saopštavanja loših vesti i zbog toga je edukacija iz ove oblasti od velikog značaja. Iz tog razloga, ova studija je sprovedena sa ciljem upoređivanja efekata edukacije bazirane na SPIKE strategiji korišćenja veština za saopštavanje loših vesti primenjujući dve vrste pristupa: igranje uloga i korišćenje multimedijalnih sadržaja.

Ova dvostruko slepa klinička studija je uključila 90 studenata akušerstva koji su nasumično podeljeni u tri grupe. Veština saopštavanja loših vesti je evidentirana u posebnoj listi pre i nakon edukacije. Pouzdanost $i$ validnost provere ove veštine su procenjene i utvrđene. Konačni podaci su analizirani primenom SPSS softvera.

Nakon edukacije, grupe koje su igrale uloge i koristile multimedijalne sadržaje su stekle bolje veštine u poređenju sa periodom pre edukacije i kontrolnom grupom. Veština saopštavanja loših vesti nakon edukacije se nije značajno razlikovala među grupama koje su igrale uloge i koristile multimedijalne sadržaje.

Rezultati su pokazali da podučavanje veštini saopštavanja loših vesti primenom multimedijalnog pristupa, koji je realizovan u vidu kursa na daljinu, može biti podjednako uspešno poput metode igranja uloga. Zbog toga se ova metoda može smatrati pogodnom zamenom metode igranja uloga u povećanju veštine saopštavanja loših vesti.

Ključne reči: igranje uloga, multimedijalni sadržaji, objavljivanje loših vesti, akušerstvo, SPIKES 
